\title{
An Assessment of Atmospheric Boundary Layer Turbulence in Maiduguri, Nigeria
}

\author{
David 0. Edokpa*, Vincent E. Weli \\ Department of Geography and Environmental Management, University of Port Harcourt, Port Harcourt, Nigeria \\ Email: ${ }^{\star}$ onojiede@gmail.com,welivinezi@yahoo.com
}

How to cite this paper: Edokpa, D.O. and Weli, V.E. (2017) An Assessment of Atmospheric Boundary Layer Turbulence in Maiduguri, Nigeria. Open Journal of Air Pollution, 6, 27-43.

https://doi.org/10.4236/ojap.2017.62003

Received: February 18, 2017

Accepted: April 21, 2017

Published: April 24, 2017

Copyright $\odot 2017$ by authors and Scientific Research Publishing Inc. This work is licensed under the Creative Commons Attribution International License (CC BY 4.0).

http://creativecommons.org/licenses/by/4.0/ (c) (i) Open Access

\begin{abstract}
This study examined the level of turbulence in the atmospheric boundary layer in Maiduguri, north-eastern Nigeria. Five years (2011-2015) temperature and wind speed data at 1000 mbar pressure level retrieved from Era-Interim Reanalysis Platform was used. These data were gotten at 6-hourly synoptic hours: $0000 \mathrm{H}, 0600 \mathrm{H}, 1200 \mathrm{H}$ and $1800 \mathrm{H}$ at $0.125^{\circ}$ grid resolution. The gradient Richardson $\left(R_{i g}\right)$ number method was utilised in analysing turbulence across three layers: 10 - $50 \mathrm{~m}$ (surface layer); 50 - $100 \mathrm{~m}$ (mid layer) and 100 $1300 \mathrm{~m}$ (upper layer). Findings shows that the surface layer is always in a turbulent state as over $95 \%$ of $R_{i g}$ values were below Richardson Critical $\left(R_{i c}\right)$ value of 0.25 with range $0.02-0.94$. However, all values across the hours were below the Richardson Termination $\left(R_{T}\right)$ value of 1 . Laminar conditions exist at the mid layer across the hours as $99.9 \%$ of $R_{i g}$ values ranging $0.88-8.02$ were greater than $R_{T}$ of $1 . R_{i g}$ values for the upper layer were largely negative and ranged between -78.71 to -724.14 . This indicates robust turbulent conditions. Turbulence generated through forced and free ascents prevailed at the surface layer and upper layer respectively. This shows that wind shear is dominant at the surface while thermal buoyancy prevails at the upper level. The months of February and September at 1200 and 1800 hours respectively are the periods of maximum (about $134 \mathrm{~m}$ ) and minimum (below $15 \mathrm{~m}$ ) heights were free convection destabilises forced convection in the study area. Relating findings to emission dispersion suggests that air pollutants will be transported across far and near distances at the upper layer and surface layers respectively. This is due to the stable nature of the mid layer that will limits vertical emission dispersion. Policy makers should ensure that potential emission sources stacks are above $50 \mathrm{~m}$ to ensure pollutants are dispersed aloft in the area.
\end{abstract}

\section{Keywords}

Turbulence, Gradient Richardson Number, Maiduguri, Emissions 


\section{Introduction}

The atmospheric boundary layer (ABL) and, more essentially, boundary layer turbulence, are indispensable elements of weather and climate [1]. They control fundamental fluxes of motion and heat amid the atmosphere and earth surfaces. The atmospheric boundary layer which begins from the surface layer up to 100 $\mathrm{m}$ generates the convective activities that influence circulations within the troposphere and beyond. The boundary layer extends beyond $1 \mathrm{~km}$ during the day and shrinks to below $500 \mathrm{~m}$ during the periods of the night [2]. The boundary layer exists in two states: laminar and turbulent boundary layers [3]. During laminar conditions, flow is restricted within a layer while erratic mixing across layers occurs at turbulent periods. Turbulence is responsible for the contraction and expansion of the boundary layer height [4]. This variation of height in relation to time is subject to the degree of mixing created by the earth surface [5]. The stronger the mixing, the higher the boundary layer height while the weaker the mixing the thinner the layer. The boundary layer obtains considerably its heat and water through the process of turbulence and is predominantly enriched by both shear and thermal forces [5] [6]. The degree of turbulence within the boundary layers shows the extent of stability situations prevalent at any location. Laminar conditions mean stable situations while turbulent conditions indicate the existence of unstable conditions. However, the amount of turbulence determines the prevailing levels of stability conditions. Studies have been conducted on atmospheric turbulence over cities and areas [7]-[12]. The level of turbulence in the boundary layer varies from one location to another due to geographical dissimilarities. This dissimilarity across locations impacts on the dispersive potentials of any local environments. The effectiveness of emission dispersion hinges on two vital components: wind speed and the strength of turbulence. While average wind speeds are reliant on local flow peculiarities, turbulence intensity relates to the generation of instability either mechanically, thermally or both [4].

Boundary layer studies are very important due to the following reasons: creatures cohabit there, energy fluxes mediate creating transfers of air masses and emission dispersion is prevalent. Also, the state of any local weather is predicted from boundary layer processes and clouds within the boundary layer regulates local weather pattern. This study intends to assess the levels of turbulence within the boundary layer in Maiduguri across three vertical layers i.e. 10 - $50 \mathrm{~m}, 50$ $100 \mathrm{~m}$ and $100-1300 \mathrm{~m}$. The Gradient Richardson $\left(R_{i g}\right)$ number method will be used to assess the levels of turbulence.

\section{Study Area}

Maiduguri is located at the tip of north-eastern Nigeria and roughly positioned between Latitude $11^{\circ} 47^{\prime} \mathrm{N}$ to $11^{\circ} 54^{\prime} \mathrm{N}$ and Longitude $13^{\circ} 05^{\prime} \mathrm{E}$ to $13^{\circ} 12^{\prime} \mathrm{E}$ (Figure 1). It has a climate pattern classified as Bsh i.e. semi-arid, hot and steppe by Koppen and Gigger [13]. Due to its closeness to the Sahel region, the effect of the hot and dry tropical continental air mass from across the Sahara desert is felt 


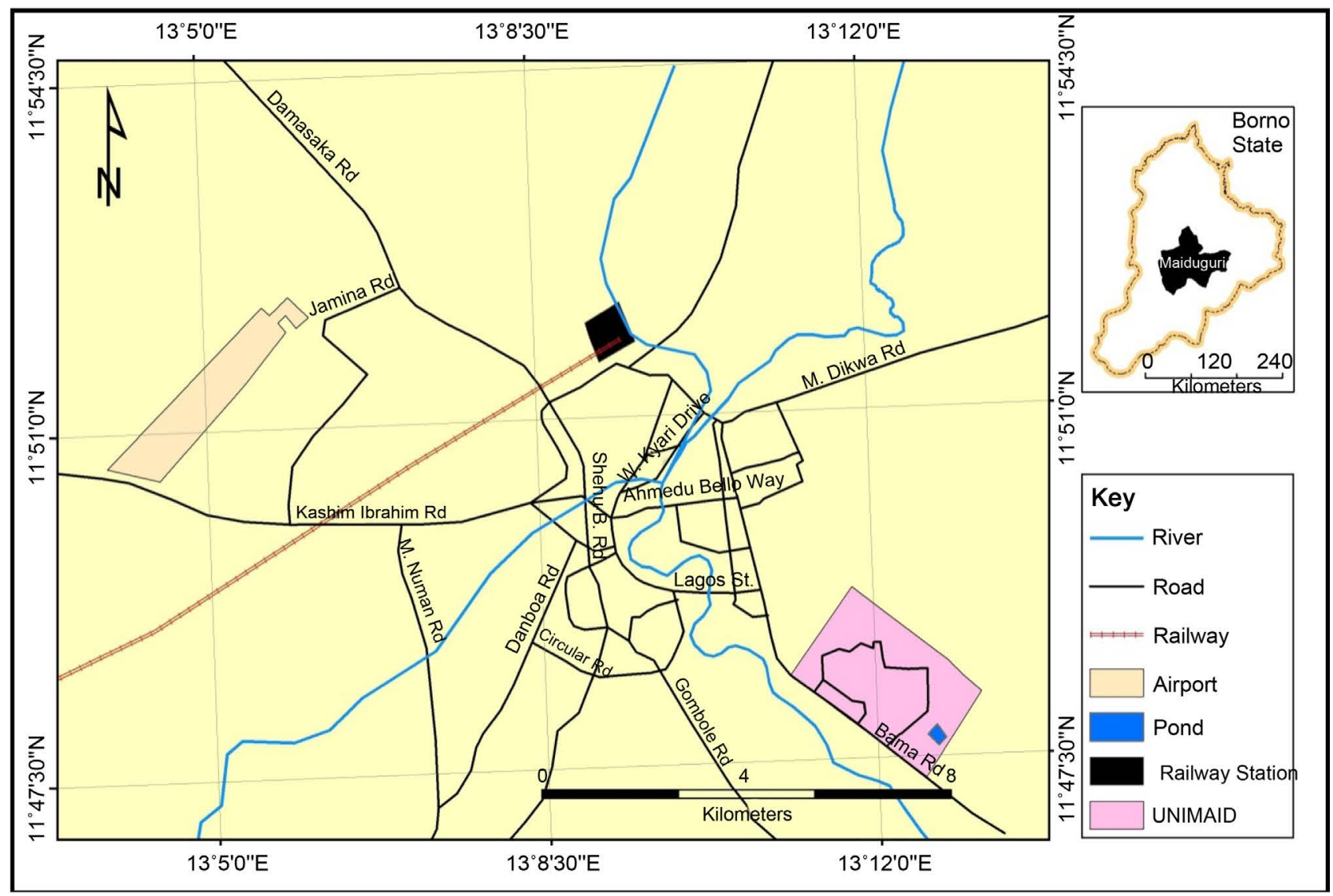

Figure 1. Map showing study area.

throughout the year. The area has two different climatic periods, which are: the hot dry spell with quite high temperatures and the wet season. The wet season is preceded by the very cold, dry and dusty Harmattan winds [14] from across the Sahara desert. During this period, temperature could drop below $16^{\circ} \mathrm{C}$. Mean temperature for the area is roughly $32^{\circ} \mathrm{C}$ and could extend up to $45^{\circ} \mathrm{C}-48^{\circ} \mathrm{C}$ [15] between the months of March to May. Mean daily sunshine hours range between 6 - 10 hours with maximum periods between October-May and minimum periods in July and August [16].

Rainfall amount over the years have ranged between 265.5 - $925.7 \mathrm{~mm}$ with mean value of $580.5 \mathrm{~mm}$ [17]. This low rainfall amount hinges on the location's constraint in accessing the buoyant warm and moist tropical maritime air mass from the Ocean. However, the area receives much of this air mass that brings rainfall during July-August periods when the ITD is overhead the northern extreme of Nigeria [18]. It has noted [19] that mean relative humidity for the area falls around $25 \%$ in January to less than $60 \%$ in August. Due to the low amount of relative humidity, cloud cover is very minimal at the area throughout the year. The mean wind velocity pattern as shown on Figures 2-4 reveals range of $2-6$ $\mathrm{m} / \mathrm{s}$ for the indicated hours i.e. 0000 and 1200 hours from December-February (DJF) as well as June-August (JJA). The wind direction pattern is north-easterly in DJF and south-westerly in JJA (Figures 2-4). 


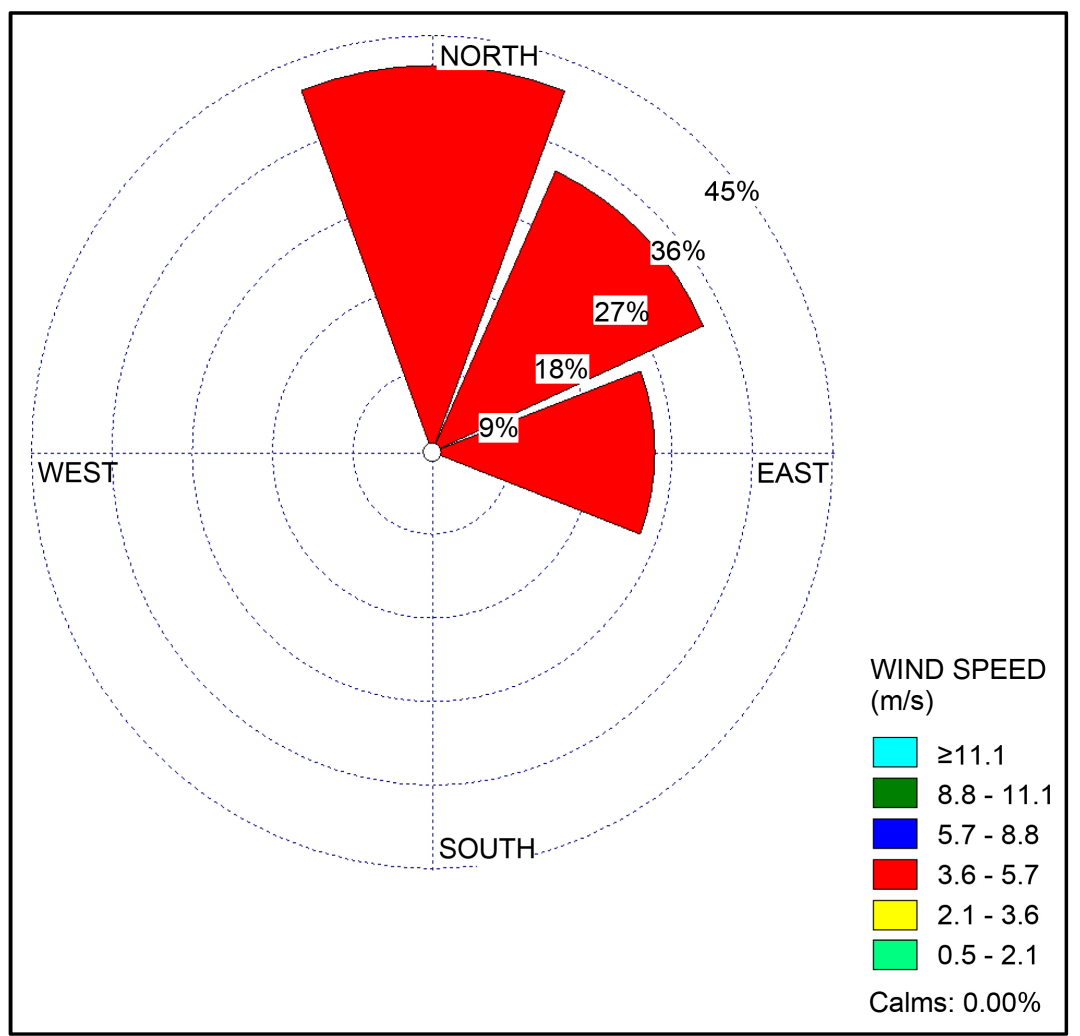

Figure 2. Wind velocity/direction pattern at $0000 \mathrm{Hr}$ in Maiduguri from December-February.

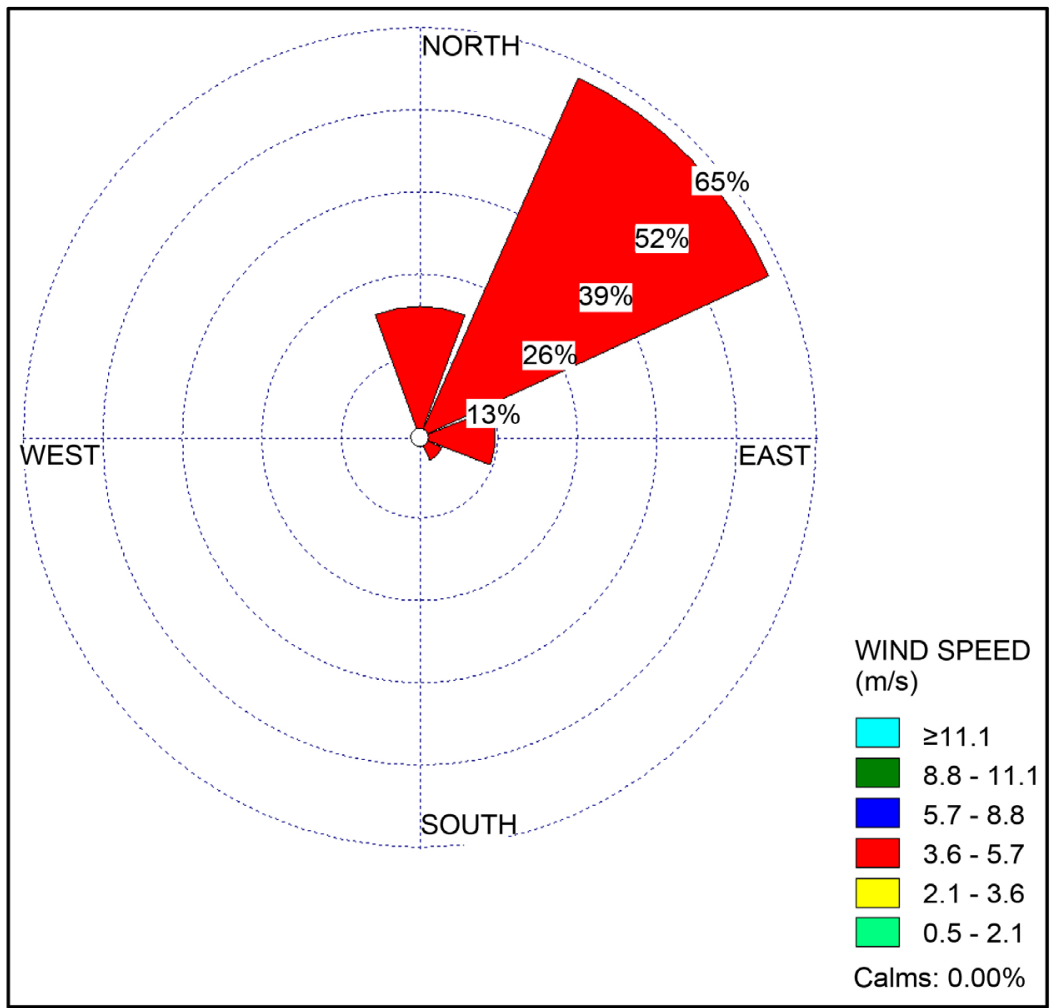

Figure 3. Wind velocity/direction pattern at $1200 \mathrm{Hr}$ in Maiduguri from December-February. 


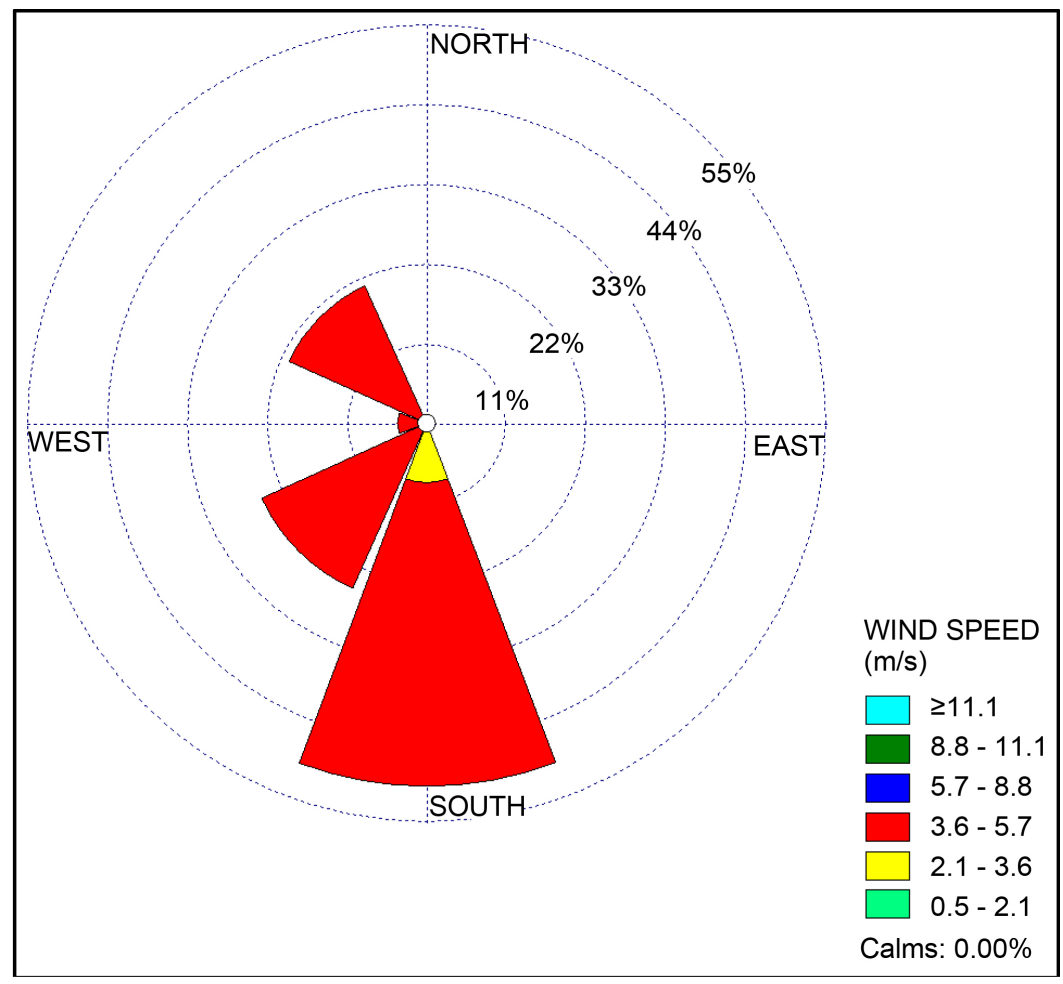

Figure 4. Wind velocity/direction pattern at $0000 \mathrm{Hr}$ in Maiduguri from JuneAugust.

\section{Data and Methodology}

\subsection{Data}

The data for used for this study were obtained from the European Centre for Medium Ranged Weather Forecast (ECMWF) Era-Interim Re-analysis data for five years (2011-2015). The Era-Interim Reanalysis Platform is the up-to-date widespread atmospheric reanalysis data and has been found resourceful in the analysis of atmospheric circulation of tropical Africa. The use of the improved Era-Interim reanalysis data has exceeded prospects and expresses positive views about the achievements in the analysis of weather data realised within the last decade. The data for the indicated period of time acquired at 0.125 degree resolution was retrieved 6-hourly at 0000, 0600, 1200 and 1800 synoptic hours. Temperature and wind speed data were obtained at pressure level of 1000 mbar which is an approximation of the surface level data.

\subsection{Methodology}

Many different models of assessing boundary layer turbulence exist. Researchers have generally combined one destabilizing force with one stabilizing force [20] and expressed these features as dimensionless ratio. Examples of these models Reynolds number, Richardson number, Rayleigh number, Ross by number and Froude number. This study utilizes the gradient Richardson number to assess the level of turbulence across three layers (10 - 50 m, 50 - $100 \mathrm{~m}$ and $100-1300$ $\mathrm{m})$. An approximate height where the destabilising force equals the stabilizing 
force through Richardson's number relations to Monin-Obukhov length (L) was estimated. Wind velocity and potential temperature were determined at $50 \mathrm{~m}$, $100 \mathrm{~m}$ and $1300 \mathrm{~m}$ altitudinal levels. MATLAB software was utilised in analysing the mathematical equations.

\subsubsection{The Application of Gradient Richardson Number $\left(R_{i g}\right)$}

When meteorologist mention the convectional Richardson number what is being referred to is the gradient Richardson number [20]. The flux Richardson number is an approximation of the gradient Richardson number. The gradient Richardson number $\left(R_{i g}\right)$ is a dimensionless ration of the restoring force to the square of the generated force [21]. It is given by:

$$
R_{i}=\frac{S}{\left(\frac{\partial u}{\partial z}\right)^{2}}
$$

where $S$ (a stability parameter) is the restoring force. The stability parameter is of the equation below.

$$
S=\frac{g}{T}\left[\left(\frac{\partial \theta}{\partial z}\right)\right]
$$

Therefore, the gradient Richardson number is given by:

$$
R_{i}=\frac{\frac{g}{T}\left[\left(\frac{\partial \theta}{\partial z}\right)\right]}{\left(\frac{\partial U}{\partial z}\right)^{2}}
$$

where,

$g$ is the gravitational acceleration $\left(\mathrm{m} / \mathrm{s}^{2}\right)$

$T$ is the mean temperature $\left({ }^{\circ} \mathrm{C}\right)$

$\theta$ is the potential temperature

$(\mathrm{d} u / \mathrm{d} z)^{2}$, is the mean wind speed $\left(\mathrm{m} / \mathrm{s}^{2}\right)$

$Z$ is the vertical height $(\mathrm{m})$.

The mean wind speed can be resolved into

$$
(\mathrm{d} u / \mathrm{d} z)^{2}=\frac{\Delta u}{Z_{m} \ln \left(Z_{2} / Z_{1}\right)}
$$

where $Z_{m}$ is the mean vertical height considered. The relationship between Monin-Obukhov Length and Richardson number is given by:

$$
L=\frac{Z_{m}}{R_{i}}
$$

The Equation (5) was used to estimate the approximate vertical distance where the restoring force equals the generated force.

\subsubsection{Estimation of Wind Velocity}

The analysed wind component of the gradient Richardson formula at $50 \mathrm{~m}, 100$ $\mathrm{m}$ and $1300 \mathrm{~m}$ was calculated using Equation (6). 


$$
\frac{V}{V_{0}}=\frac{\ln \left(H / Z_{0}\right)}{\ln \left(H_{0} / Z_{0}\right)}
$$

where $V_{0}$ is the referenced surface wind velocity and $V$ is the estimated wind velocity at the specified vertical height $(H)$. The assumed roughness length for Maiduguri was 0.03 i.e. for open flat terrain with scattered settlements [22].

\subsubsection{Estimation of Atmospheric Pressure and Potential Temperature}

The estimated atmospheric pressure at $50 \mathrm{~m}, 100 \mathrm{~m}$ and $1300 \mathrm{~m}$ levels was determined with the following equation:

$$
P=P_{0} \mathrm{e}^{-\left(\frac{h}{h_{0}}\right)}
$$

where, $P$ is the atmospheric pressure in bars, $h$, the height in $(\mathrm{km}), P_{0}$, pressure at height; $h=0\left(P_{0}=1\right.$ bar) and $h_{0}=7$ (an approximate scale height for the atmosphere). The correspondent potential temperature $(\theta)$ at the indicated altitudes was calculated with the following equation [23].

$$
\theta_{z}=T_{z}\left(\frac{P_{s}}{P}\right)^{\frac{R}{C_{p}}}
$$

where, " $T_{z}$ " is the temperature (K) of the air parcel at reference height $(z)$, " $R$ " is the gas constant of air and " $C_{p}$ " is the specific heat capacity at constant pressure. The ratio $\left(R / C_{p}\right)$ is given as $(0.286)$ for air. At any level, $z$, there is a temperature $\left(T_{z}\right)$ and a corresponding potential temperature $\left(\theta_{z}\right)$.

\subsubsection{The Richardson Number Level of Turbulence}

The Richardson number $\left(R_{i}\right)$ is very important because it can identify the onset and cessation of turbulence. Theoretical and laboratory studies recommend that lamina flow turn out to be turbulent when $R_{i}$ is smaller than the critical Richardson $\left(R_{i c}\right)$ number of 0.25 [20]. Another term is the Richardson Termination $\left(R_{T}\right)$ level of 1 . This indicates the termination of turbulence. Turbulent flow becomes laminar when $R_{i}>R_{T}$. It is noted that $R_{i c}$ is between $0.21-0.25$. The critical Richardson number only relates to local gradients. The thinner the layer, the closer the $R_{i}$ will likely be to 0.25 [20].

It has been disclosed [24] that as the gradient Richardson number $\left(R_{i g}\right)$ approaches 0.25 , vertical fluxes become weak. However, [25] have acknowledged that turbulence could persist for $R_{i}$ values greater than 1 , due to numbers of experimental studies conducted. An upsurge in turbulence and a decline in wind shear is observed when $R_{i}$ number turns negative, conforming to unstable situations during daytime. Throughout night-time, for positive $R_{i}$ values, the strength of turbulence reduces and wind shear is high [26].

\section{Results and Discussion}

The results from analysis of the mean gradient Richardson $\left(R_{i g}\right)$ number across the layers for the respective hours are shown on Table 1. Findings show that the first layer $(10-50 \mathrm{~m})$ across the hours is in a turbulent state as all $R_{i g}$ values were 
Table 1. Gradient Richardson number values in Maiduguri for the specified hours.

\begin{tabular}{|c|c|c|c|c|c|c|c|c|}
\hline \multirow[b]{2}{*}{ Month } & \multicolumn{4}{|c|}{ 0000HR } & \multicolumn{4}{|c|}{ 0600HR } \\
\hline & $10-50 \mathrm{~m}$ & $50-100 \mathrm{~m}$ & $100-1300 \mathrm{~m}$ & $\mathrm{~L}$ & $\begin{array}{c}10-50 \\
\mathrm{~m}\end{array}$ & $\begin{array}{c}50- \\
100 \mathrm{~m}\end{array}$ & $\begin{array}{c}100-1300 \\
\mathrm{~m}\end{array}$ & $\mathrm{~L}$ \\
\hline JAN & 0.24 & 2.03 & -141.32 & 41.99 & 0.15 & 2.06 & -186.97 & 60.77 \\
\hline FEB & 0.12 & 1.99 & -139.15 & 74.37 & 0.15 & 2.03 & -184.01 & 61.75 \\
\hline MAR & 0.09 & 2.97 & -121.98 & 84.53 & 0.12 & 2.01 & -158.69 & 74.3 \\
\hline APR & 0.02 & 1.97 & -137.00 & 75.54 & 0.15 & 2.99 & -159.12 & 58.69 \\
\hline MAY & 0.02 & 1.26 & -137.14 & 82.19 & 0.12 & 1.28 & -109.76 & 80.91 \\
\hline JUN & 0.08 & 1.27 & -98.15 & 109.14 & 0.07 & 1.29 & -81.18 & 123.54 \\
\hline JUL & 0.24 & 2.01 & -139.67 & 42.49 & 0.09 & 1.29 & -111.24 & 92.99 \\
\hline AUG & 0.19 & 2.02 & -212.69 & 51.36 & 0.12 & 2.03 & -160.94 & 73.26 \\
\hline SEP & 0.18 & 5.35 & -248.32 & 44.37 & 0.15 & 3.60 & -213.55 & 56.71 \\
\hline OCT & 0.24 & 3.54 & -245.98 & 37.45 & 0.24 & 3.58 & -248.78 & 37.02 \\
\hline NOV & 0.24 & 2.01 & -180.96 & 42.72 & 0.19 & 3.59 & -128.96 & 45.89 \\
\hline \multirow[t]{2}{*}{ DEC } & 0.09 & 2.03 & -125.39 & 86.09 & 0.15 & 2.06 & -187.10 & 60.73 \\
\hline & \multicolumn{4}{|c|}{$1200 \mathrm{H}$} & \multicolumn{4}{|c|}{$1800 \mathrm{H}$} \\
\hline JAN & 0.08 & 1.28 & -98.61 & 108.64 & 0.12 & 1.28 & -138.78 & 81.22 \\
\hline FEB & 0.07 & 0.88 & -79.48 & 134.42 & 0.23 & 1.26 & -136.61 & 50.19 \\
\hline MAR & 0.14 & 1.25 & -78.71 & 73.39 & 0.23 & 1.94 & -135.28 & 43.87 \\
\hline APR & 0.14 & 1.86 & -153.69 & 64.81 & 0.28 & 1.94 & -176.13 & 37.99 \\
\hline MAY & 0.47 & 3.46 & -288.49 & 22.37 & 0.47 & 3.45 & -240.04 & 22.35 \\
\hline JUN & 0.18 & 3.49 & -288.81 & 47.73 & 0.24 & 5.23 & -291.14 & 35.79 \\
\hline JUL & 0.14 & 1.98 & -180.30 & 63.02 & 0.48 & 3.54 & -354.59 & 21.94 \\
\hline AUG & 0.18 & 2.00 & -181.80 & 51.72 & 0.33 & 8.02 & -440.79 & 25.46 \\
\hline SEP & 0.65 & 3.53 & -436.89 & 17.89 & 0.94 & 7.97 & -724.14 & 10.75 \\
\hline OCT & 0.47 & 3.49 & -289.59 & 22.13 & 0.24 & 5.25 & -350.32 & 35.76 \\
\hline NOV & 0.14 & 1.26 & -87.55 & 71.89 & 0.23 & 1.97 & -155.74 & 43.46 \\
\hline DEC & 0.07 & 1.92 & -89.77 & 118.22 & 0.09 & 1.99 & -123.22 & 87.61 \\
\hline
\end{tabular}

below the Richardson Termination point of 1 . However, over $96 \%$ of the $R_{i g}$ values in this layer were below the Richardson critical level of 0.25 . The $R_{i g}$ values across the second layer $(50-100 \mathrm{~m})$ have indicated an entirely lamina condition except at $1200 \mathrm{H}$ in February when mean $R_{i g}$ value was below the $R_{i T}$ of 1 i.e. 0.88 .

Turbulence conditions within the atmospheric boundary layers differs beginning from the surface layer to the outer layer [2]. It has been noted that the surface layer (up to $50 \mathrm{~m}$ ) is characterised by continuous intense [5] and small scale turbulence created by wind shear and thermal activities. The next layer is the less-turbulent layer (laminar boundary layer) in close contact with the earth surface. This layer establishes a buffer between the surface layer and the free atmosphere [5]. It has been disclosed that top the stable boundary limit in the planetary boundary layer is lower than $400 \mathrm{~m}$ [27].

Results from the third layer (100 - $1300 \mathrm{~m})$ with more vertical stretch than the 
other layers have indicated more turbulent conditions across the hours. All $R_{i g}$ values were largely negative. This indicates strongly unstable situations over the layer. It has been emphasised that largely negative $R_{i}$ values indicates turbulent or unstable situations [22] and this is due to massive free ascents of air mass compared to very minimal forced ascents.

Results from Table 1 also highlighted the estimated height where free ascent begins to displace forced accent within the study area. The mean maximum estimated height of displacement recorded was $134.42 \mathrm{~m}$ at $1200 \mathrm{H}$ in February while the lowest was $17.89 \mathrm{~m}$ at $1200 \mathrm{H}$ in September (Table 1). This shows that thermal ascents of air parcel in the study area are prevalent at altitudinal distances below $140 \mathrm{~m}$.

A correlation of surface layer wind shear values based on Richardson number [9] with atmospheric stability categories for Inland and Coastal sites in Northeast region of Brazil are shown on Table 2.

Furthermore, $R_{i g}$ values from this study at the first layer $(10-50 \mathrm{~m})$ compare well with the wind shear outcomes on Table 2. This further confirms the turbulent nature of surface layer in Maiduguri which when related with in-land site values in northeast Brazil on Table 2 shows that the surface layer is unstable for most of the time especially during the $0000 \mathrm{H}$ and $0600 \mathrm{H}$. At the $0000 \mathrm{H}$ in Maiduguri, there exists terrestrial radiation from the earth surface which is being modified by surface wind speed thereby generating unstable condition at the surface layer. However, the layer above it will be laminar or stable due to the warm air overriding the cool surface.

Additionally, the $R_{i g}$ results for the study area indicated turbulent patterns in two dimensional grade: the first at the surface layer $(10-50 \mathrm{~m})$ and at the upper layer $(100-1300 \mathrm{~m})$ during 0000, 0600, 1200 and 1800 hours. Results for the surface layer were minor positives while that at the upper layer were largely negative. This implies that turbulence due to wind shear dominated the surface layer while that resulting from thermal or free ascent prevailed at the upper layer considered in this study. However, turbulence due to free convention is stronger than that due to wind shear. The mid layer was in a state of laminar condition throughout the period considered. Wind velocity pattern at the surface shows a mean range of $2-6 \mathrm{~m} / \mathrm{s}$ for specified night and day hours (Figures 2-5) and this

Table 2. Atmospheric stability on wind parameters in northeast Brazil.

\begin{tabular}{ccc}
\hline \multirow{2}{*}{ Stability Categories } & \multicolumn{2}{c}{ Wind Shear $\left(R_{i}\right.$ Values $)$} \\
\cline { 2 - 3 } & In-land Site & Coastal Site \\
\hline Very Unstable & 0.14 & 0.08 \\
Unstable & 0.22 & 0.13 \\
Near Neutral & 0.36 & 0.16 \\
Stable & 0.38 & 0.20 \\
Very Stable & 0.34 & 0.27 \\
\hline
\end{tabular}

Source: Vieira and Sampaio, 2012. 


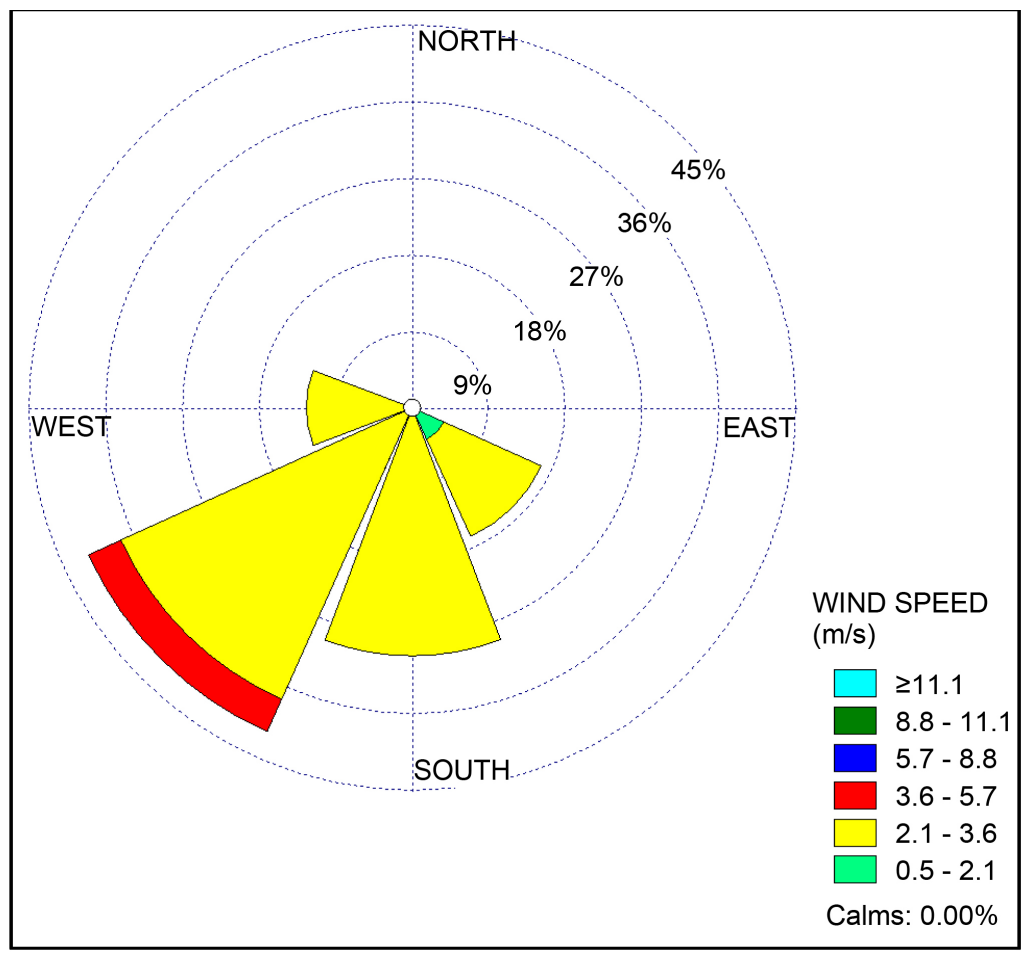

Figure 5. Wind velocity/direction pattern at $1200 \mathrm{Hr}$ in Maiduguri from June-August.

is capable of modifying thermals that may arise at night and during the day. Therefore, turbulence could be regulated by the intervention of varying wind velocity across layers. Massive sensible heat exchange takes place at tropical desert where above $60 \mathrm{kly}$ per annum is transferred to the atmosphere [28]. The study area which is of close proximity to the Saharan desert will be almost similar in trend. This sensible heat is moderated by wind shear at the surface which results in turbulent events. The stable mid layer couple with the re-radiated terrestrial radiation by dominant high clouds in the study area could have caused the unstable nature of the upper layer due to increased air temperature [29]. It has been admitted [30] that across the Saharan desert, warming from surface sensible heat flux dominates the surface layer while radiative cooling is foremost upward from the planetary layer. This radiative cooling is extremely linked with latent heat releases which generate penetrating heat almost throughout the troposphere. This process makes the upper layer turbulent and in a state of unstable conditions.

\subsection{Mean Monthly Trend Analysis of Turbulence Pattern in Study Area}

The monthly trends of Rig for the various layers in relation to the specified synoptic hours are displayed on Figures 6-8. During the $0000 \mathrm{H}$ on Figure 6, the months of April and May are more turbulent due to forced convention at the surface layer $(10-50 \mathrm{~m})$ while September and October (Figure 7) are most laminar (i.e. very stable) at the mid layer $(50-100 \mathrm{~m})$. At the upper layer (100 - 


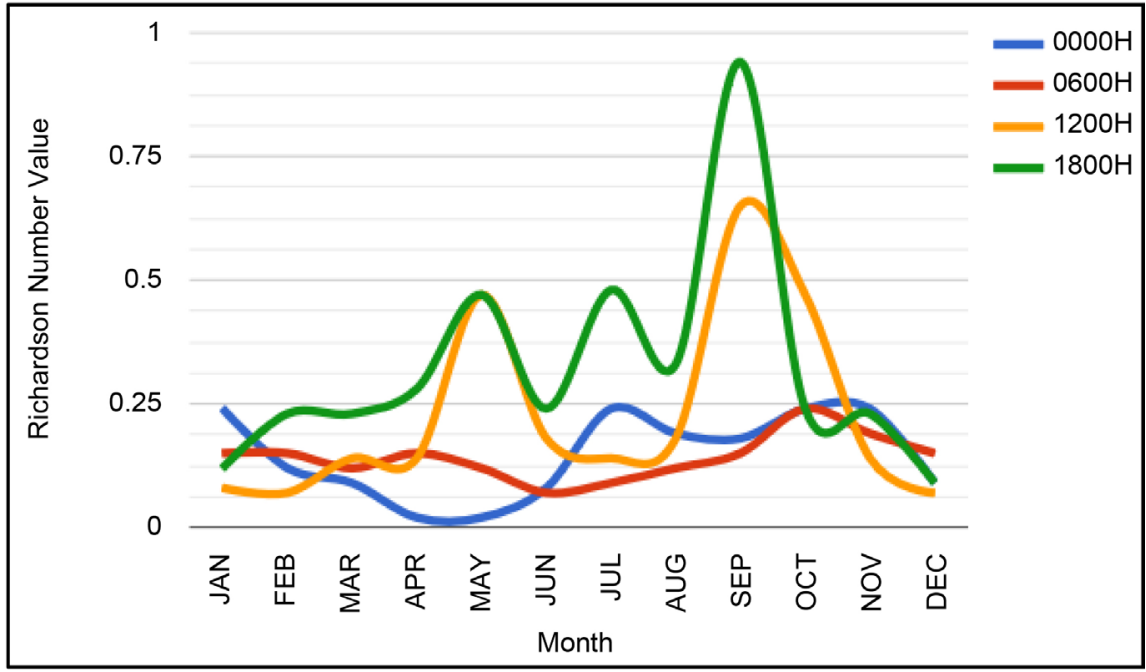

Figure 6. The monthly $R_{i g}$ trend at the $10-50 \mathrm{~m}$ layer for the specified hours.

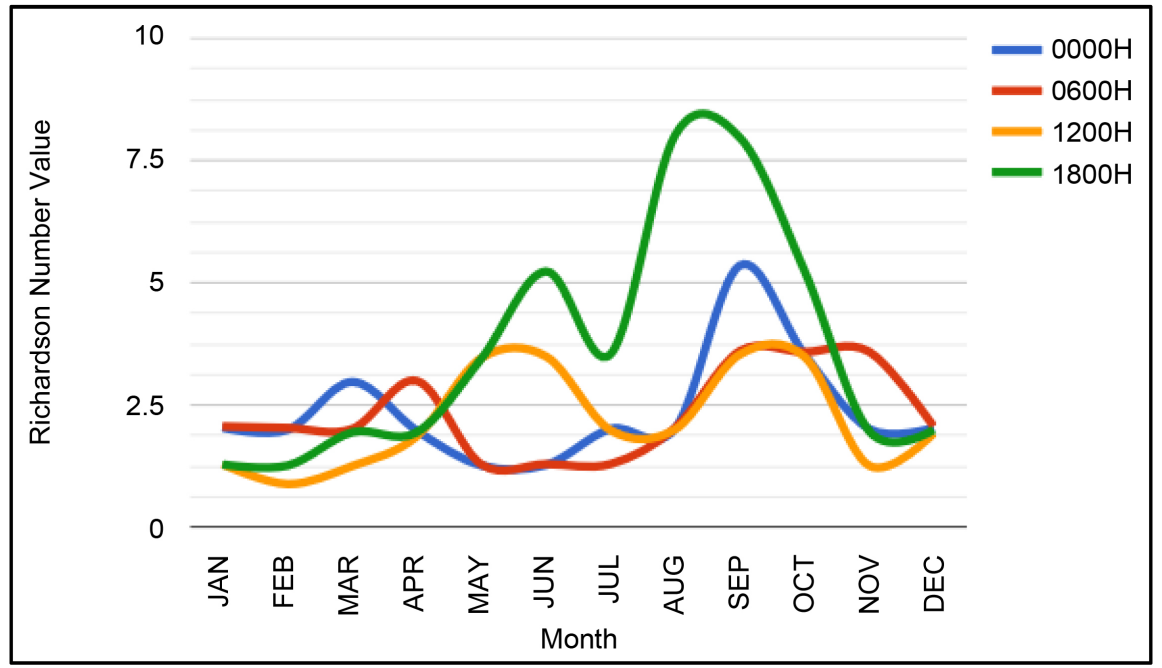

Figure 7. The monthly $R_{i g}$ trend at the $50-100 \mathrm{~m}$ layer for the specified hours.

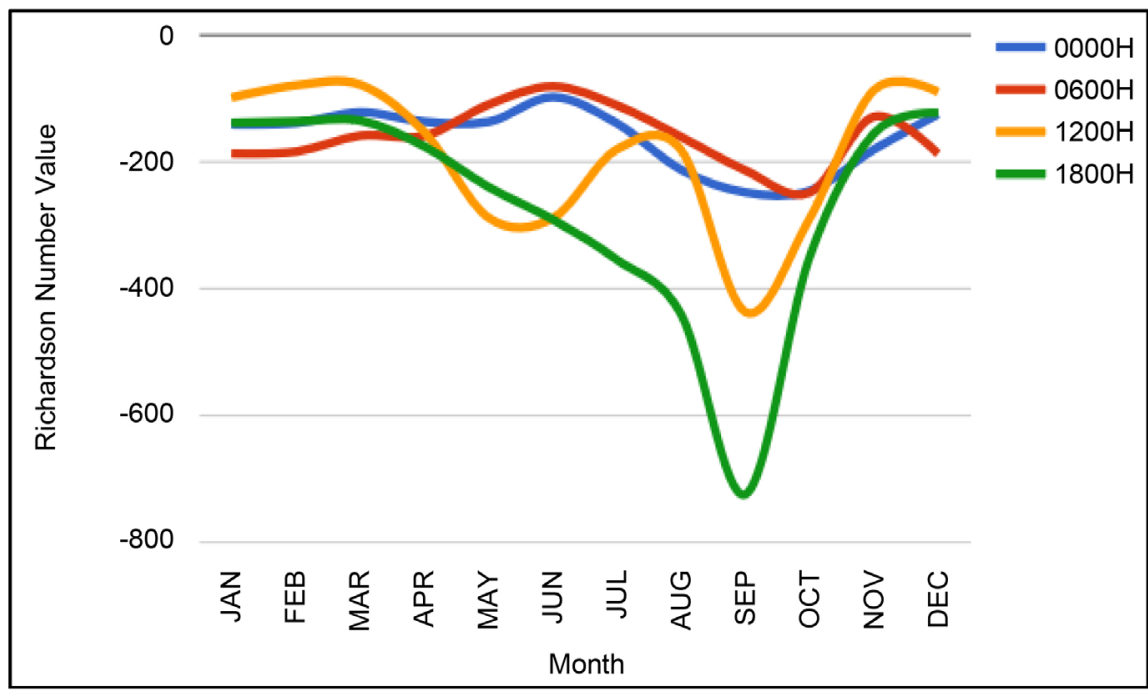

Figure 8. The monthly $R_{i g}$ trend at the $100-1300$ m layer for the specified hours. 
$1300 \mathrm{~m}$ ) during the same hour, September and October reveals the most turbulent periods due to free convection (Figure 8). This coincides with the peak/ cessation of rainy season where the moist and warm tropical maritime air mass from the Atlantic Ocean is at its maximum. The ITD reaches the Sahel region between the months June-July [31] and starts retreating by September across study area. Also the easterly wind which undercut the tropical maritime air mass during this time is higher in strength leading to very turbulent situations.

During $0600 \mathrm{H}$ period, June experiences slightly higher turbulence than the rest months at the $10-50 \mathrm{~m}$ layer while laminar conditions is stronger during the months of September to November at the 50 - $100 \mathrm{~m}$ layer (Figure 6 and Figure 7). At the upper layer $(100-1300 \mathrm{~m})$ during the hour, turbulent conditions due to free convection are least in June and stronger in October (Figure 8).

The turbulence pattern at $1200 \mathrm{H}$ on Figure 6 shows that at the surface layer turbulent is least in the months of May and September and more turbulent during the months of November to February. However, strong laminar conditions prevail between May-June as well as September-October respectively.

While September maintains high turbulence pattern due to free ascent at the upper layer $(100-1300 \mathrm{~m})$, the months of November-March is least in the fray (Figure 8). At $1800 \mathrm{H}$, the months of December and January show stronger turbulent situations due to wind shear at the surface layer (Figure 6). However, at the mid layer $(50-100 \mathrm{~m})$, laminar conditions were stronger from August to October (Figure 7). At the upper layer in Figure 8, September retained the strongest turbulence due to free convection with least months from December to March.

Result analysis from the expression of relationship between Richardson number and Monin-Obukhov Length which estimates the mean height where free ascent of air mass starts dominating forced ascents is shown on Figure 9. It is revealed that free ascents destabilises forced ascents below $140 \mathrm{~m}$ during $1200 \mathrm{H}$ period in February and below $20 \mathrm{~m}$ during $1800 \mathrm{H}$ period in September. This

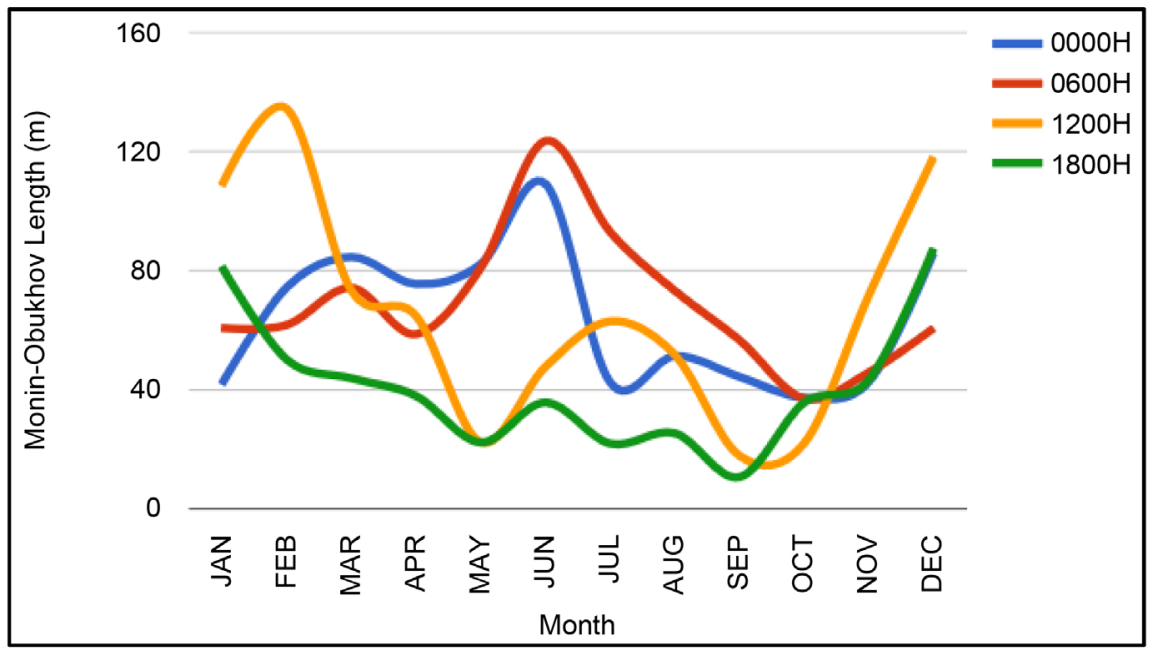

Figure 9. The 6-hourly monthly variation of vertical heights where free ascent destabilises forced ascent. 
shows that the months of February and September at 1200 and 1800 hours are the periods of maximum and minimum heights were free convection destabilises forced convection in the study area. It has been disclosed [32] that the stable boundary layer is generated by wind shear and thereafter destabilised by negative buoyancy and viscosity.

\subsection{Effect of Turbulence Pattern on Boundary Layer Activities in the Study Area}

$R_{i g}$ results indicate that the strength of turbulence within the boundary layer of the study location changes amid layers. The application of $R_{i g}$ as a turbulent indicator also reveals the pattern of atmospheric stability conditions prevalent in the study area. This will be critical to the events that occur at the planetary layer such as emissions from various anthropogenic and natural sources, micrometeorological variations as well as the level of comfort experienced by inhabitants of the boundary layer most especially at the surface layer. The most critical factor in air pollution analysis is the level of turbulence within the boundary layer as it has intense effect on the dispersion of ground level emissions. Result analysis show that pollutant dispersions will be enhanced at $1800 \mathrm{H}$ from February to November due to the lower level (below $50 \mathrm{~m}$ ) at which free ascent destabilises forced ascent (Figure 9). This will allow for convective overturning that disperses pollutants away from ground surface even at moderate wind velocity. Pollutant dispersions will be worse during December to February at $1200 \mathrm{H}$; June to July at $0600 \mathrm{H}$; December to January at $1800 \mathrm{H}$ and June at $0000 \mathrm{H}$. This is due to the higher altitude at which free ascent destabilises forced ascent (Figure 9). During inversion periods at night when inversion level might be at the surface layer below an emission source of more than $50 \mathrm{~m}$, pollutants will be trapped at the mid layer. However, the degree of turbulence at the upper layer of $100-1300$ $\mathrm{m}$ may create windows for the escape of trapped emissions from the mid layer $(50-100 \mathrm{~m})$. When emission sources are below inversion level at the surface layer, pollutant dispersions will be concentrated within the surface layer and distributed effectively by moderate to strong wind velocity. At low wind velocity, emissions will be stagnated hence impacting receptors downwind of the source. The inversion depth during the night is governed by turbulent mixing, controlled strongly by dynamic stability [33]. The unstable nature at the upper layer $(100-1300 \mathrm{~m})$ will be effective in transporting emissions across boundaries as dispersions will take place above the mid layer $(50-100 \mathrm{~m})$ that is stable and slow to vertical movements. Energy transfer within laminar layers is by conduction and vertical exchanges of heat and moisture are very slow [28]. The turbulent pattern at the upper layer could also engender violent storms like squall line occasionally. This will be enhanced when the easterly winds that intermittently come in contact with either the moist tropical maritime air mass or the highpressure subsidence air mass that characterises the study area from across the Saharan desert. The dusty Hamattan wind that is prevalent at the area especially during the dry season will impact receptors when transported both at the surface 
and upper layer. This will have adverse effects on the health of habitats and concentrations will be significant both below and aloft at close and far distances. It has been noted that the dust emissions [31] in the desert region are related to the occurrence of high wind velocities at the surface. Additionally, in the aviation sector, the Richardson number is utilised as a rough measure of expected air turbulence. The $R_{i g}$ values in the range 0.1 to 10 are typical [34]. Values below unity indicate significant turbulence. The $R_{i g}$ values obtained in this study suggest that the aviation industry in the study area must continue to monitor the levels of turbulence in the area for efficient air traffic.

\section{Conclusion}

Turbulence activities in the atmospheric boundary layer affect both weather processes and other vital activities that take place within the layer. Maiduguri, an urban centre located in northeastern Nigeria responds to such realities. Using the Era-Interim Re-analysis data (2011-2015), examining turbulence pattern across the boundary layers in the area have shown that the surface layer (10 - 50 $\mathrm{m})$ is always in a turbulent state. The analysed gradient Richardson number $\left(R_{i g}\right)$ across the synoptic hours: $0000 \mathrm{H}, 0600 \mathrm{H}, 1200 \mathrm{H}$ and $1800 \mathrm{H}$ show that over $95 \%$ of values were small positive and below the Richardson critical $\left(R_{i c}\right)$ value of 0.25 . However, all $R_{i g}$ values at the surface layer were below the Richardson Termination $\left(R_{T}\right)$ value of 1 . Studies has revealed that turbulence exist due to more of wind shear when $R_{i g}$ values are lesser than $R_{T}$. On the other hand, $R_{i g}$ findings shows that the mid layer $(50-100 \mathrm{~m})$ indicates laminar situation as a results of $R_{i g}$ values greater than 1 . It was a different pattern at the upper level considered in this study $(100-1300 \mathrm{~m})$ as $R_{i g}$ values were largely negative indicating a strongly turbulent layer. In the study area, turbulence due to forced and free convention was prevalent. While the former was more prevalent at the surface layer, the later was prevalent at the upper layer. Turbulence due to forced ascent results from surface wind shear. That of free ascent could be as a result of the subsidence of high-pressure stable air mass that descends to the surface from across the Sahara desert. This creates unstable conditions as the air mass gains heat and assumes horizontal flow to low-pressure area. The turbulence pattern at the area suggest that air pollution will be transported to longer distance at the upper layer due to the laminar situations at the mid layer. Also, air pollution will be dispersed within the surface layer if the emission source stack is below $50 \mathrm{~m}$ both at low and high wind speeds. However, if the emission source stack is above $50 \mathrm{~m}$, emission dispersion will take place aloft. Results also suggest that wind turbines development for power generation will be appropriate within the surface layer when compared to $R_{i}$ wind shear values in northeast Brazil.

\section{Acknowledgements}

The authors show profound appreciation to the anonymous reviewers whose observations have improved the content of this study. Also the authors appreciate this Journal platform for the opportunity given to publish this study. 


\section{References}

[1] National Science Foundation (2015) Boundary-Layer Turbulence and Surface Exchange. Mesoscale\&Microscale Meteorology Laboratory, Arlington.

[2] Arya, P. (1998) Introduction to Micrometeorology. 2nd Edition, Academic Press, San Diego.

[3] Mikkelson, T. (2003) Modeling of Pollutant Transport in the Atmosphere. Atmospheric Physics Division. Wind Department, Risq National Laboratory, Denmark.

[4] Mauritsen, T. (2007) On the Arctic Boundary Layer. PhD Thesis at Stockholm University, Stockholm University, Sweden.

http://www.mpimet.mpg.de/fileadmin/staff/mauritsenthorsten/Thesis_Thorsten_M auritsen_introduction.pdf

[5] Oke, T.R. (1987) Boundary Layer Climates. 2nd Edition, Methuen Publishers, Lagos.

[6] Capman, N. (2011) Turbulence Intensity in Complex Environments and Its Influence on Small Wind Turbines. Department of Earth Sciences, Uppsala University, Uppsala.

https://www.bixia.se/globalassets/privat/filer/miljofonden/2011-1-carpman_turbule nce_intensity.pdf

[7] Roth, M. (2000) Review of Atmospheric Turbulence over Cities. Quarterly Journal of the Royal Meteorological Society, 126, 941-990. https://doi.org/10.1002/qj.49712656409

[8] Weiss, A. (2002) Determination of Thermal Stratification and Turbulence of the Atmospheric Surface Layer over Various Types of Terrain by Optical Scintillometry. A Published Edited Version of Dissertation Submitted to the SWISS Federal Institute of Technology, Zurich.

[9] Vieira, C.F.A. and Sampaio, E.F. (2012) Analysing the Impact of Atmospheric Stability on Wind Parameters in Northeast Region of Brazil. Brazil Wind Power, Siemens Energy International.

[10] Friedrick, K., Lundquist, J.K., Aitken, M., Kalina, E.A. and Mashall, R.F. (2012) Stability and Turbulence in the Atmospheric Boundary Layer: A Comparison of Remote Sensing and Tower Observations. Geophysical Research Letters, 39, 1-6. https://doi.org/10.1029/2011g1050413

[11] Desmond, C.J. and Watson, S. (2014) A Study of Stability Effects in Forested Terrain. Journal of Physics, Conference Series, 555, 1-18. https://doi.org/10.1088/1742-6596/555/1/012027

[12] Weli, V.E. and Emenike, G.C. (2016) Turbulent Weather Events and Aircraft Operations: Implications for Aviation Safety at the Port Harcourt International Airport, Nigeria. International Journal of Weather, Climate Change and Conservation Research, 2, 11-21. www.eajournals.org

[13] Peel, M.C., Finlayson, B.L. and McMahon, T.A. (2007) Updated World Map of the Köppen-Geiger Climate Classification. Hydrology and Earth System Sciences, 11, 1633-1644. https://doi.org/10.5194/hess-11-1633-2007

[14] Ogugbuaja, V.O. and Barsisa, L.Z. (2001) Atmospheric Pollution in North-East Nigeria: Measurement and Analysis of Suspended Particulate Matter. Bulletin of the Chemical Society of Ethiopia, 15, 109-117.

[15] Lawal, J.R., Bello, A.M., Balami, S.Y., Dauda, J., Malgwi, K.D., Ezema, K.U., Kazim, M. and Biu, A.A. (2016) Prevalence of Haemoparasites in Village Chickens (Gallus gallusdomesticus) Slaughtered at Poultry Markets in Maiduguri, North-Eastern Nigeria. Journal of Animal Science and Veterinary Medicine, 1, 39-45. 
http://www.integrityresjournals.org/jasvm/publications/2016/pdf/04lawal\%20et\%20 al.pdf

[16] Wikipedia (2017) Maiduguri Climate. https://en.wikipedia.org/wiki/Maiduguri

[17] Obot, N.I., Chendo, M.A.C., Udo, S.O. and Ewona, I.O. (2010) Evaluation of Rainfall Trends in Nigeria for 30 years (1978-2007). International Journal of the Physical Sciences, 5, 2217-2222. http://www.academicjournals.org/article/article1380875532_Obot\%20et\%20al.pdf

[18] Ojo, O. (1977) The Climates of West Africa. Heinemann, Ibadan.

[19] Dammo, M.N., Yadima, S.G. and Sangodoyin, A.Y. (2016) Observed Trend of Changes in Relative Humidity across North-East Nigeria (1981-2010). Civil and Environmental Research, 8, 73-76.

[20] Stull, R.B. (1988) An Introduction to Boundary Layer Meteorology. Springer, Netherland. https://doi.org/10.1007/978-94-009-3027-8

[21] Muir, D.M. (2004) Air Pollution Control Technology. Department of Chemical and Process Engineering, University of Strathclyde Publications, United Kingdom.

[22] Bailey, D.T. (2000) Meteorological Monitoring Guidance for Regulatory Modelling Applications. U.S. Environmental Protection Agency. Office of Air and Radiation; Office of Air Quality Planning and Standards.

[23] Dickerson, R.R. and Li, Z.Q. (2015) Physics and Chemistry of the Atmosphere I. Department of Atmospheric \& Oceanic Sciences, University of Maryland. AOSC 620 Lecture 2.

https://www.google.com.ng/url?sa=t\&rct=j\&q=\&esrc=s\&source=web\&cd=23\&cad= rja\&uact=8\&ved=0ahUKEwiXxLrFpKvTAhXGwxQKHSfMDtg4FBAWCC4wAg\&u rl=http\%3A\%2F\%2Fwww.atmos.umd.edu\%2F russ\%2F620_02_water2013.ppt\&usg $=\mathrm{AFQjCNG6oVOYuNlfbe5QQyhrNcevefNncA \& sig2=iA54X89qklc \_ AwvF8UmSIQ}$

[24] Grachev, A.A., Andreas, E.L., Fairall, C.W., Guest, P.S. and Persson, P.O.G. (2012) The Critical Richardson Number and Limits of Applicability of Local Similarity Theory in the Stable Boundary Layer. Boundary Layer Meteorology, 147, 51-82. https://arxiv.org/ftp/arxiv/papers/1202/1202.5066.pdf https://doi.org/10.1007/s10546-012-9771-0

[25] Galperin, B., Sukoriansky, S. and Anderson, P.S. (2007) On the Critical Richardson Number in Stably Stratified Turbulence. Atmospheric Science Letters, 8, 65-69. https://doi.org/10.1002/asl.153

[26] Texier, O., Bezault, C., Girald, N., Houbart, J.-C. and Pham, S. (2012) Results of Integration of Atmospheric Stability in Wind Power Assessment through CFD Modelling. http://meteodyn.com/wp-content/uploads/2012/05/Integration-of-atmospheric-sta bility-in-wind-power-assessment-through-CFD-modeling-2010.pdf

[27] Garratt, J.R. (1992) The Atmospheric Boundary Layer. University Press, Cambridge.

[28] Ayoade, J.O. (2004) Introduction to Climatology for the Tropics. 2nd Edition, Spectrum Books, Ibadan.

[29] Gounou, A., Guichard, F. and Couvreux, F. (2012) Observations and Diurnal Cycles over a West African Meridional Transect: Pre-Monsoon and Full-Monsoon Season. Boundary Layer Meteorology, 144, 329-357. https://doi.org/10.1007/s10546-012-9723-8

[30] Li, W.P., Chineke, T.C., Liu, X. and Wu, G.X. (2001) Atmospheric Diabatic Heating and Summertime Circulation in Asia-Africa Area. Advances in Atmospheric Sciences, 18, 257-269. https://doi.org/10.1007/s00376-001-0018-0

[31] Karam, D.B., Flamant, C., Knippertz, P., Reitebuch, O., Pelon, J. and Chong, M. 
(2008) Dust Emissions over the Sahel Associated with the West African Monsoon Inter-Tropical Discontinuity Region: A Representative Case-Study. Quarterly Journal of the Royal Meteorological Society, 134, 621-634.

https://doi.org/10.1002/qj.244

[32] Grachev, A.A. (2015) Stable Boundary Layers. Science Review, 12-14 May. https://www.esrl.noaa.gov/psd/events/2015/review/pdf/presentations/psd-review-th eme2a-grachev.pdf

[33] Wang, S., Zheng, X. and Jiang, Q. (2012).Strongly Sheared Stratocumulus Convection: An Observationally Based Large-Eddy Simulation Study. Atmospheric Chemistry and Physics, 12, 5223-5235. https://doi.org/10.5194/acp-12-5223-2012

[34] Wikipedia (2016) Richardson Number.

http://en.wikipedia.org/wiki/Richardson_number

Submit or recommend next manuscript to SCIRP and we will provide best service for you:

Accepting pre-submission inquiries through Email, Facebook, LinkedIn, Twitter, etc. A wide selection of journals (inclusive of 9 subjects, more than 200 journals)

Providing 24-hour high-quality service

User-friendly online submission system

Fair and swift peer-review system

Efficient typesetting and proofreading procedure

Display of the result of downloads and visits, as well as the number of cited articles

Maximum dissemination of your research work

Submit your manuscript at: http://papersubmission.scirp.org/

Or contact ojap@scirp.org 